\title{
Penyaluran Zakat Dalam Upaya Mengembangkan Modal Usaha (Studi Kasus Pada BAZNAS Kabupaten Bungo)
}

\author{
Muklisin1 \\ Fakultas Ekonomi dan Bisnis Islam Institut Agama Islam (IAI) Yasni Bungo \\ E-Mail :muklisinmukidi@gmail.com
}

Iffah Pohan ${ }^{2}$

Institut Agama Islam (IAI) Yasni Bungo

E-Mail : iffahpohahanjambi@gmail.com

\begin{abstract}
Zakat distribution is an activity of distributing and utilizing zakat aimed at zakat mustahik. The distribution of zakat is carried out by the amil zakat body which is formed by the government which is organized in the form of an agency or institution. The Amil Zakat Agency is called the National Zakat Agency, abbreviated as BAZNAS. BAZNAS is a zakat management institution established by the government to collect and distribute zakat to zakat mustahik. Zakat can aim to help mustahik in developing a business. The purpose of this study is to determine the distribution of zakat in an effort to develop business capital. This research was conducted at BAZNAS Bungo Regency in 2018 in an effort to develop productive businesses.
\end{abstract}

Keywords: Distribution, Zakat, Business Capital

\begin{abstract}
ABSTRAK :
Penyaluran zakat adalah suatu kegiatan pendistribusian, serta pendayagunaan zakat yang ditujukan kepada para mustahik zakat.Penyaluran zakat dilakukan oleh badan amil zakat yang dibentuk oleh pemerintah yang diorganisasikan dalam bentuk suatu badan atau lembaga.Badan Amil Zakat tersebut dinamakan dengan Badan Amil Zakat Nasional disingkat dengan BAZNAS.BAZNASadalah lembaga pengelolaan zakat yang didirikan oleh pemerintah untuk menghimpun dan menyalurkan zakat kepada para mustahik zakat.Zakat bisa bertujuan untuk membantu para mustahik dalam mengembangkan usaha.Tujuan penelitian ini adalah untuk mengetahui penyaluran zakat dalam upaya mengembangkan modal usaha.Penelitian ini dilakukan pada BAZNAS Kabupaten Bungotahun 2018 dalam upaya mengembangkan usaha produktif.
\end{abstract}

Kata Kunci :Penyaluran, Zakat, Modal Usaha

\footnotetext{
${ }^{1}$ Dosen Fakultas Ekonomi dan Bisnis Islam Institut Agama Islam (IAI) Yasni Bungo

2 Dosen Tetap Institut Agama Islam (IAI) Yasni Bungo
} 
Muklisin ,Iffah Pohan: Penyaluran Zakat Dalam...

\section{A. PENDAHULUAN}

Dalam Undang-Undang Pengelolaan Zakat No. 23 tahun 2011, pada Pasal 16 ayat 1 menyatakan bahwa; "dalam melaksanakan tugas dan fungsinya BAZNAS Provinsi, dan BAZNAS Kabupaten/Kota dapat membentuk unit pengumpulan zakat (UPZ) pada instansi pemerintah, badan usaha milik Negara, badan usaha milik daerah, perusahaan swasta, dan perwakilan Republik Indonesia di luar negeri serta dapat membentuk UPZ pada tingkat kecamatan, kelurahan atau nama lainnya dan tempat lainnya ". ${ }^{3}$ Hal ini dimaksudkan agar penghimpunan dana zakat bisa terlaksana dengan baik, karena semakin banyak lembaga yang menghimpun dana zakat maka capaian perolehan dana zakat otomatis juga akan besar.

Zakat adalah salah satu rukun Islam yang wajib dipenuhi oleh setiap muslim. Menunaikan zakat adalah urusan individu, sebagaimana pemenuhan kewajiban seorang muslim. Apabila seorang mukmin telah beribadah dan melaksanakan kewajibannya disisi Allah swt dan mendapat ganjaran sebagaimana yang Allah telah janjikan.

Zakat dalam pelaksanaannya harus ditetapkan dan diatur oleh agama dan Negara, baik dari segi jenis harta yang dizakatkan, para wajib zakat (muzzaki) maupun para penerima zakat (mustahik), sampai pada pengelolaannya oleh pihak ketiga, dalam hal ini pemerintah atau lembaga yang ditunjuk oleh pemerintah untuk mengelola zakat demi kemaslahatan ummat.

Sebagai Negara dengan jumlah mayoritas muslim, Indonesia sebenarnya tidak hanya mengambil rumusan langka-langkah strategis dari konsep Negara kesejahteraan, melainkan juga dapat merujuk pada konsep dan paradigma kesejahteraan ummat yang ada dalam ajaran Islam. Padahal yang kedua inilah, para pemikir muslim meyakini bahwa di dalam prinsip dan ajaran Islam tentang zakat mengandung visi dan misi kesejahteraan masyarakat. Kenyataan sejarah menuturkan bahwa pengelolaan zakat yang dipraktekkan pada masa Rasulullah saw menjadi bukti yang cukup kuat bagi upaya pembentukan Negara dan warga Negara yang bermartabat. ${ }^{4}$

3Undang-Undang RI Nomor 23 tahun 2011 Tentang Pengelolaan Zakat.

${ }^{4}$ Said Saad Marathon, Ekonomi Islam Ditengah Krisis Ekonomi Global, Jakarta ; Zikrul Hakim, cetakan ke 3, 2007, hal. 34 
Manajemen pengelolaan zakat adalah untuk meningkatkan betapa ummat Islam dengan struktur sosial yang sekarang, berikut kemenangan pada kuantitas, tetap saja masih terasa tawar unttuk pengelolaan dana zakat. Hanya sebagian kecil potensi dana zakat yang berhasil dikumpulkan dan didistribusikan kepada yang berhak. Bila melihat pengelolaan dana zakat hanya berlaku sporadik atau kurang terorganisir. ${ }^{5}$

Pengumpulan zakat seharusnya merupakan sesuatu yang terprogram dan terencana, termasuk ditentukan jadwalnya dengan jelas, dan tetap berlandaskan untuk beribadah kepada Allah swt dengan ikhlas.Dalam pengelolaan zakat perlu diperhatikan bahwa pembayaran zakat hendaknya mengetahui kemana harta zakatnya itu disalurkan dan dimanfaatkan. Badan amil zakat harus mempunyai dokumen dan data atau pembukuan yang rinci mengenai jumlah uang zakat yang diterima, orang yang membayarnya, kemana digunakan, dan semacamnya.

Ketentuan-ketentuan hukum mengenai zakat diterapkan dan dikembangkan dengan merumuskan kembali hal-hal yang berhubungan dengan sumber zakat (harta yang wajib dizakatkan) dan pendayagunaan (pendistribusian) zakat, yang ditopang oleh manajemen yang baik, maka peran dan fungsi zakat akan dapat terwujud.

Berdasarkan Undang-Undang Nomor 23 Tahun 2011, bahwa organisasi yang berhak mengelola zakat terbagi menjadi dua bagian, yakni organisasi yang tumbuh atas prakarsa masyarakat dan disebut Lembaga Amil Zakat (LAZ) serta organsisai yang dibentuk oleh pemerintah dan disebut dengan Badan Amil Zakat (BAZ).

Kedua bentuk organsasi memiliki kesamaan tujuan, yaitu bertujuan mengelola dana zakat dan sumber-sumber dana sosial yang lain secara maksimal untuk keperluan ummat. Misi mulia yang diemban ini jangan sampai berbenturan dalam pelaksanaan programnya. (UU No. 23 Tahun 2011 Tentang Pengelolaan Zakat)

Di dalam Pasal 1 butir 2 dan 5, pengertian dari zakat adalah harta yang wajib dikeluarkan oleh seorang muslim atau badan usaha untuk diberikan kepada yang berhak menerimanya sesuai dengan syariat Islam. Sedangkan pengertian Muzaki adalah seorang muslim atau badan usaha yang berkewajiban menunaikan zakat. Zakat

${ }^{5}$ Arif Mufraini, Akuntansi Dan Manajemen Zakat;Mengomunikasikan Kesadaran Dan Membangun Jaringan, Jakarta: Kencana Prenada Media Group; 2006, hal. 123 
Muklisin ,Iffah Pohan: Penyaluran Zakat Dalam...

memiliki peranan yang sangat strategis dalam upaya pengentasan kemiskinan atau pengembangan ekonomi. Berbeda dengan sumber keuangan untuk pembangunan yang lain. 6

Zakat harus memiliki mekanisme dan sistem kontrol yang jelas.Hal tersebut bisa dilakukan dengan lembaga terkait. Dengan adanya kewajiban membayar zakat maka orang yang membayar zakat tidak akan pernah habis dan menjadi amal ibadah bagi yang membayarnya.Pengelolaan zakat adalah suatu kegiatan perencanaan, pengorgansasian, pelaksanaan, pengawasan terhadap pengumpulan dan pendistribusian, serta pendayagunaan zakat. Pengelolaan zakat dilakukan oleh badan amil zakat yang dibentuk oleh pemerintah yang diorganisasikan dalam bentuk suatu badan atau lembaga. Pengumpulan zakat dilakukan oleh badan amil zakat dengan cara menerima atau mengambil dari muzakki atas dasar pemberitahuan dari muzaki. ${ }^{7}$

Badan Amil Zakat (BAZ) sebagai lembaga pengelolaan zakat yang didirikan oleh pemerintah ternyata sistem manajemen pengelolaannya masih belum optimal dan kurang dipercaya masyarakat atau muzakki.Artinya kinerjanya masih perlu ditingkatkan lagi untuk menjaga kesinambungan manfaat penggunaan zakat dan infak tersebut.

Prinsip zakat dalam tatanan sosial ekonomi mempunyai tujuan untuk memberikan pihak tertentu yang membutuhkan untuk menghimpun dirinya selama satu tahun kedepan dan bahkan diharapkan sepanjang hidupnya. Dalam konteks ini, zakat didistribusikan untuk dapat mengembangkan ekonomi baik melalui keterampilan yang menghasilkan maupun dalam bidang perdagangan. ${ }^{8}$

Target penghimpunan dana zakatnya di BAZNAS Kabupaten Bungo yaitu para pegawai negeri sipil (PNS) yang ada di Kabupaten Bungo. Selain itu lembaga BAZNAS Kabupaten Bungo sendiri juga membuka pintu lebar-lebar untuk para muzakki yang ingin menyalurkan zakatnya walaupun itu orang di luar Kabupaten Bungo. 2006, hal. 70

${ }^{6}$ Nuruddin Ali, Zakat Sebagai Instrument Dalam Kebijakan Fiscal, Jakarta; Raja Grafindo Perkasa;

${ }^{7}$ Sondang P. Siagian, Manajemen Strategik, Jakarta : Bumi Aksara, 2005, hal. 42

8Musyidi, Akuntansi Zakat kontemporer, Bandung; Remaja Rosdakarya; 2006, hal. 171 
Karena itu, pengelolaan dan penyaluran dana zakat yang baik akan menciptakan kepercayaan pada masyarakat sehingga masyarakat akan terdorong menyalurkan dananya pada Badan Amil Zakat (BAZ) dari pada menyalurkannya langsung pada mustahik zakat.Diharapkan dengan adanya lembaga BAZNASKabupaten Bungo maka akan mampu meningkatkan perekonomian ummat melalui pemberian dan pemberdayaan zakat melalui program unit usaha kecil menengah (UMKM). Sehingga para penerima zakat atau mustahik zakat yang memiliki usaha akan terbantu dalam pengembangan modal usaha. Selai itu juga unit usaha kecil menengah (UMKM) di Kabupaten Bungo juga diharapkan mampu membuka lowongan pekerjaan baru yang dapat mengurangi penganguran di Kabupaten Bungo.

\section{B. METODOLOGI PENELITIAN}

Pada penelitian ini pendekatan yang digunakan adalah menggunakan metode penelitian kualitatif dengan pendekatan deskriptif (deskriptif kualitatif).Dimana dalam pendekatan kualitatif ini sebagai prosedur penelitian yang menghasilkan data deskriptif berupa kata-kata tertulis atau lisan dari orang-orang dan perilaku yang dapat diamati. ${ }^{9}$

Penulis menggunakan penelitian kualitatif karena mempunyai tiga alasan yaitu :Pertama, lebih mudah mengadakan penyesuaian dengan kenyataan yang berdimensi ganda. Kedua, lebih mudah menyajikan secara langsung hakikat hubungan antara peneliti dan subjek penelitian.Dan yang ketiga, memiliki kepekaan dan daya penyesuaian diri dengan banyak pengaruh yang timbul dari pola-pola nilai yang dihadapi.

Sedangkan menggunakan pendekatan deskriptif, karena tidak dimaksudkan untuk menguji hipotesis, tetapi hanya menggambarkan suatu gejala atau keadaan yang diteliti secara apa adanya serta diarahkan untuk dapat memaparkan fakta-fakta, kejadian-kejadian secara sistematis dan akurat. 
Muklisin ,Iffah Pohan: Penyaluran Zakat Dalam...

\section{HASIL PENELITIAN DAN PEMBAHASAN}

1. Zakat

\section{a. Pengertian Zakat}

Ditinjau dari segi bahasa, kata zakat merupakan kata dasar (masdar) dari zakat yang berarti berkah, tumbuh, bersih dan baik.Sesuatu itu zaka, berarti tumbuh dan berkembang dan seorang itu zaka, berarti orang itu baik.Dan bila seseorang diberi sifat zaka dalam arti baik, maka berarti orang itu lebih banyak mempunyai sifat yang baik.Seorang itu zaki, berarti seorang yang lebih banyak sifat-sifat orang baik.

Zakat dari segi istilah fikih berarti "sejumlah harta tertentu yang diwajibkan Allah diserahkan kepada orang-orang yang berhak "disamping berarti "mengeluarkan jumlah tertentu itu sendiri. Jumlah yang dikeluarkan dari kekayaan itu disebut zakat karena yang dikeluarkan itu menambah banyak, membuat lebih berarti dan melindungi kekayaan itu dari kebinasaan.Adapun zakat menurut syarak berarti hak yang wajib (dikeluarkan dari harta).

\section{b. Syarat-Syarat Wajib Zakat}

1) Milik Sempurna

Yang dimaksud dengan milik sempurna adalah kemampuan pemilik harta mentransaksikan barang miliknya tanpa campur tangan orang lain pada waktu datangnya kewajiban membayar zakat.

2) Berkembang Secara Riil Atau Estimasi

Bahwa harta tersebut harus dapat berkembang secara rill atau secara estimasi.Yang dimaksud dengan pertumbuhan rill adalah pertambahan akibat perkembangbiakan atau perdagangan.

Sedangkan yang dimaksud dengan estimasi adalah harta yang nilainya mempunyai kemungkinan bertambah seperti emas, perak dan mata uang yang semuanya mempunyai kemungkinan pertambahan nilai dengan memperjual belikannya.

3) Sampai Nisab

Nisab adalah sejumlah harta yang mencapai jumlah tertentu yang ditentukan secara hukum, yang mana harta tidak wajib dizakati jika kurang dari ukuran tersebut.

4) Melebihi Kebutuhan Pokok

Harta tersebut merupakan kelebihan dari nafkah dari kebutuhan asasi bagi kehidupan muzaki dan orang yang berada dibawah tanggungannya seperti istri, anak, pembantu dan asuhannya.

5) Cukup Haul

Haul adalah perputaran harta satu nisab dalam 12 bulan qomariah (hijriyah). Harta yang wajib zakat tersebut telah dimiliki selama satu haul secara sempurna.

\section{c. Prinsip-Prinsip Zakat}

Sejalan dengan ketentuan dasar bahwa zakat dapat disebut sebagai pajak kekayaan seseorang, maka dapat ditarik beberapa prinsip yaitu : 
1) Zakat hanya dikenakan pada harta yang mempunyai sifat secara potensial dapat berkembang, baik secara rill berkembang atau tengah disiapkan untuk berkembang, bahkan juga yang tidak dikembangkan ditimbun dalam simpanan.

2) Zakat dibayarkan dari harta yang terkena wajib zakat, jika harta itu merupakan benda bergerak kecuali jika tidak mungkin. Misalnya zakat harta dagangan tidak dibayarkan berupa uang harganya.

3) Zakat dipungut dari harta yang benar-benar hartanya milik dan berada di tangan wajib zakat. Dengan piutang yang berada di tangan debitur tidak wajib dikeluarkan zakatnya oleh pemiliknya sebagai kreditur. Zakat yang tidak dibayarkan pada waktunya tetapi menjadi tanggungan para wajib zakat dan menyangkut semua harta yang terkena wajib zakat.

4) Zakat tetap merupakan kewajiban disamping pajak-pajak yang ditetapkan atas dasar peraturan perundang-undangan Negara. Zakat merupakan kewajiban keagamaan yang hanya dikenakan terhadap harta kekayaan penganut agama Islam. Sedangkan pajak dikenakan terhadap semua penduduk Negara, baik yang beragama Islam maupun yang lainnya. 10

\section{d. Hikmah Zakat}

Meskipun zakat hakikatnya adalah kewajiban atas orang kaya untuk memenuhi kebutuhan hak fakir miskin dan lain-lainnya.Namun amat besar pula hikmahnya yang diperoleh para wajib zakat dari adanya kewajiban tersebut. Sesuai dengan arti zakat yang antara lain adalah suci, maka zakat itu diwajibkan dengan tujuan agar dapat menyucikan hati si wajib zakat dari sifat kikir yang merupakan watak pembawaan manusia.

Diantara hikmah zakat adalah :

1) Mensyukuri karunia illahi, menumbuh suburkan harta dan pahala serta membersihkan diri dari sifat-sifat kikir, dengki, iri serta dosa.

2) Melindungi masyarakat dari bahaya kemiskinan dan akibat kemelaratan.

3) Mewujudkan rasa solidaritas dan kasih sayang antara sesama manusia.

4) Manifestasi semangat kegotong royongan dan tolong menolong dalam kebaikan dan takwa.

5) Mengurangi kefakir miskinan yang merupakan masalah sosial.

6) Membina dan mengembangkan stabilitas sosial.

7) Salah satu jalan mewujudkan keadilan zakat. ${ }^{11}$

\section{Sejarah BAZNAS Kabupaten Bungo}

Zakat merupakan pranata keagamaan yang memiliki kaitan secara fungsional dengan upaya pemecahan masalah-masalah sosial kemanusiaan, seperti pengentasan

10 Ali Hasan, Zakat Dan Infak Salah Satu Solusi Mengatasi Problema Sosial di Indoesia, Jakarta: Kencana Prenada Media Group : 2008, hal. 56

${ }^{11}$ Muhammad Daud Ali, Sistem Ekonomi Islam Zakat Dan Wakaf, Jakarta : UI Press; 1988, hal. 41 
kemiskinan dan kesenjangan sosial akibat perbedaan dalam kepemilikan kekayaan.Agar zakat bisa menjadi sumber dana yang dapat dimanfaatkan bagi kesejahteraan terutama untuk mengentaskan masyarakat dari kemiskinan dan menghilangkan kesenjangan sosial, maka perlu adanya pengelolaan zakat yang lebih serius, profesional dan bertanggung jawab yang dilakukan secara bersama oleh masyarakat dan pemerintah.

Untuk itulah dibentuk badan amil zakat daerah (BAZDA) berdasarkan surat keputusan Bupati Bungo Nomor 452 tahun 2004 pada tanggal 1 Desember 2004. Kemudian pada tahun 2014 ditetapkan perubahan transformasi dari BAZDA menjadi BAZNAS oleh pemerintah pusat yang sesuai dengan ketentuan Undang-Undang Nomor 23 Tahun 2011 Tentang Pengelolaan Zakat dan Peraturan Pemerintah Nomor 14 Tahun 2014.

Badan Amil Zakat Nasional (BAZNAS) di Kabupaten Bungo yang disingkat dengan BAZNAS KAbupaten Bungo adalah salah satu lembaga pemerintah yang diberi tanggung jawab untuk mengelola zakat di Kabupaten Bungo Provinsi Jambi sesuai dengan amanat Undang-Undang Nomor 38 Tahun 2003 tanggal 23 Juni 2003 atas usul Kepala Kantor Kementerian Agama Kabupaten Bungo. ${ }^{12}$

\section{Visi dan Misi BAZNAS Kabupaten Bungo}

Adapun yang menjadi visi dan misi BAZNAS Kabupaten Bungo adalah ;

Visinya adalah untuk mewujudkan badan amil zakat Bungo sebagai pengelola zakat yang amanah, professional, dan mandiri untuk meningkatkan taraf hidup mustahik.

Misi BAZNAS Kabupaten Bungo adalah ;

a. Membangun kepercayaan masyarakat untuk menyalurkan zakat melalui BAZNAS Kabupaten Bungo.

b. Meningkatkan fungsi, manfaat dan daya guna zakat.

c. Menggali potensi zakat dan sumber-sumber zakat yang ada.

d. Menciptakan mekanisme kerja, prosedur kerja dan pemberdayaan organisasi secara optimal.

\section{Pengelolaan dan Penerimaan Zakat di BAZNAS Kabupaten Bungo}

Sejak dibentuknya kebijakan terkait pengelolaan zakat dan ditetapkannya pada tanggal 23 Juni 2003, BAZNAS Kabupaten Bungo telah menunjukkan dampak positif bagi pengelolaan zakat di Kabupaten Bungo.Adapun pengelolaan zakat oleh BAZNAS

12 Muhammad Zaki. "Faktor-Faktor Yang Mempengaruhi Muzakki Untuk Membayar Zakat Melalui Badan Amil Zakat Daerah (BAZDA) Kabupaten Bungo, Provinsi Jambi". (Tesis, Program Pascasarjana IAIN Sumatera Utara, 2012), Hal. 100 
Muklisin ,Iffah Pohan: Penyaluran Zakat Dalam...

Kabupaten Bungo sebagai berikut selama tiga tahun terakhir.Tampaknya, pendekatan lama yang cenderung menunggu bola sudah tidak tepat lagi diterapkan untuk saat ini khususnya di Kabupaten Bungo dalam pengumpulan zakat.

Dalam hal ini BAZNAS Kabupaten Bungo harus bisa menciptakan suatu strategi sebagai metode dalam pengumpulan zakat yang professional.Professional dalam mengatur segala bidang mulai dari anggaran, sistem, pengukuran, kinerja, penerapan sasaran, pemilihan jenis usaha, program kerja para amil zakat dan lainnya.

Dalam hal ini BAZNAS Kabupaten Bungo untuk mengumpulkan dana zakat dan infak dari para Muzakki yang nantinya akan disalurkan kepada mereka yang membutuhkan yaitu mereka yang masuk ke dalam 8 asnab (penerima zakat).Dibawah ini akan kami sajikan daftar tabel rekapitulasi penerimaan zakat dan infak di BAZNAS Kabupaten Bungo.

Tabel. 1

Rekapitulasi penerimaan zakat infak BAZNAS Kabupaten Bungo, tahun 2016-2018

\begin{tabular}{|l|l|l|l|}
\hline NO & \multicolumn{1}{|c|}{ TAHUN } & \multicolumn{1}{|c|}{ JUMLAH ZAKAT DAN } & \multicolumn{1}{|c|}{ KETERANGAN } \\
INFAK & \\
\hline 1 & 2016 & Rp. 2.584 .657 .051 & Pertahun \\
\hline 2 & 2017 & Rp. 3.096.801.504 & Pertahun \\
\hline 3 & 2018 & Rp.1.844.675.022 & Semester 1 \\
\hline
\end{tabular}

Sumber : Dokumen, rekapitulasi penerimaan zakat BAZNAS Kabupaten Bungo

Dari penjelasan tabel diatas dapat kita lihat bahwa penerimaan Zakat dan Infak pada BAZNAS Kabupaten Bungo mengalami kenaikan dari tahun 2016 sampai tahun 2017.Sementara itu pada tahun 2018 baru dilaksanakan pada semester 1 belum selesai dalam hal penarikan oleh panitia amil zakat BAZNAS Kabupaten Bungo. 
Muklisin ,Iffah Pohan: Penyaluran Zakat Dalam...

\section{Penyaluran Zakat BAZNAS Kabupaten Bungo}

Dana zakat dan infak yang telah terkumpulkan oleh BAZNAS Kabupaten Bungo, dalam hal ini didistribusikan sesuai dengan peraturan dan syariat islam. Adapun prioritas kepada penerima atau mustahik tergolong kepada delapan asnab yaitu : fakir, miskin, amil, muallaf, riqob, orang yang berhutang (garimun), fisabilillah dan ibnu sabil.

Dalam kurun waktu tahun 2017 sampai 2018, BAZNAS Kabupaten Bungo telah mendistribusikan zakat konsumtif kepada penerima zakat atau mustahik zakat yang tersebar di 17 kecamatan yang ada di Kabupaten Bungo. Dengan jumlah dana zakat yang didistribusikan sebagai berikut.

Tabel. 2

Penyaluran Zakat oleh BAZNAS Kabupaten Bungo tahun 2017-2018

\begin{tabular}{|c|c|c|c|c|c|}
\hline NO & \multicolumn{2}{|c|}{ NAMA KEGIATAN } & JUMLAH & JUMLAH & TOTAL \\
\hline 1 & $\begin{array}{l}\text { Penyaluran } \\
\text { Konsumtif } \\
2017\end{array}$ & $\begin{array}{l}\text { Zakat } \\
\text { tahun }\end{array}$ & 6.800 orang & $\begin{array}{l}\text { Rp.200.000/ } \\
\text { orang }\end{array}$ & Rp.1.360.000.000 \\
\hline 2 & $\begin{array}{l}\text { Penyaluran } \\
\text { Konsumtif } \\
2018\end{array}$ & $\begin{array}{l}\text { Zakat } \\
\text { tahun }\end{array}$ & 8.500 orang & $\begin{array}{l}\text { Rp.150.000/ } \\
\text { Orang }\end{array}$ & Rp.1.275.000.000 \\
\hline
\end{tabular}

Sumber : Dokumen, rekapitulasi pendistribusian zakat BAZNAS Kabupaten Bungo

Dalam tabel diatas dapat kita lihat bahwa penyaluran dana zakat konsumtif pada tahun 2017 dan tahun 2018 mengalami kenaikan jumlah penerima zakat (mustahik zakat) yaitu dari 6.800 orang menjadi 8.500 orang. Sedangkan besaran jumlah zakat yang diterima justru mengalami penurunan yaitu dari Rp.200.000/ orang menjadi Rp. 150.000/orang. Sementara total pendistribusian zakat oleh BAZNAS Kabupaten Bungo dari tahun 2017 - 2018 mengalami penurunan jumlah yaitu dari total Rp. 1.360.000.000 menjadi Rp. 1.275.000.000.

\section{Penyaluran Zakat Dalam Upaya Pengembangan Modal Usaha}

Dalam penyaluran zakat yang dilakukan oleh BAZNAS Kabupaten Bungo kepada para mustahik zakat selain yang 8 asnaf tersebut di atas, BAZNAS Kabupaten Bungo 
juga menyalurkan zakat dalam bentuk modal usaha sehingga diharapkan mampu meningkatkan peningkatan perekonomian khususnya dalam bidang yang bergerak di unit usaha kecil menengah (UMKM) di Kabupaten Bungo. Menciptakan peluang usaha bagi para mustahik membutuhkan analisis keputusan yang tepat.Dengan analisis ini, maka di harapkan BAZNAS Kabupaten Bungo dapat menentukan skala prioritas mana yang memiliki tingkat kemaslahatan yang penting.

Dengan adanya peluang usaha bagi para mustahik maka diharapkan mampu mengembangkan usaha kecil menengah dengan modal berasal dari zakat akan menyerap tenaga kerja. Contoh usaha kecil menengah (UMKM) yaitu seperti usaha idustri rumahan yang ada di Kabupaten Bungo di Dusun Purwabakti berupa pengolahan pisang menjadi pisang sale, kripik pisang, kripik tempe, kripik ubi, bolu sawit, dodol dan lain-lain.Kegiatan BAZNAS Kabupaten Bungo ini patut dicontoh dan diikuti karena juga dapat mengurangi pengangguran khsususnya di Kabupaten Bungo berkat bantuan dari pihak BAZNAS.

Program ini adalah program berupa pemberian dana zakat kepada para mustahik dalam rangka membantu meningkatkan perekonomian para mustahik. Dimana bentuk program ini adalah pemberian modal usaha berupa alat tukang, binatang ternak, bibit tanaman, dan ikan, serta pemberian modal usaha dan gerobak bagi pedagang kaki lima.

Selama tahun 2018 BAZNAS Kabupaten Bungo terbukti sudah dua kali menyalurkan bantuan modal usaha secara bertahap.Adapun besaran penyaluran zakat untuk modal usaha adalah dapat dilihat pada tabel sebagai berikut.

Tabel. 3

Daftar Penyaluran Modal Usaha dari Zakat oleh BAZNAS Kabupaten Bungo Tahun 2018

\begin{tabular}{|c|c|c|c|c|}
\hline NO & NAMA KEGIATAN & $\begin{array}{c}\text { JUMLAH } \\
\text { MUSTAHIK }\end{array}$ & $\begin{array}{c}\text { JUMLAH } \\
\text { ZAKAT }\end{array}$ & TOTAL \\
\hline 1 & $\begin{array}{l}\text { Penyaluran Modal } \\
\text { Usaha tanggal } 07 \\
\text { Februari } 2018\end{array}$ & 65 orang & $\begin{array}{l}\text { Rp.2.000.000/ } \\
\text { orang }\end{array}$ & Rp.130.000.000 \\
\hline 2 & $\begin{array}{l}\text { Penyaluran Modal } \\
\text { Usaha tanggal } 07 \text { Mei }\end{array}$ & 161 orang & $\begin{array}{l}\text { Rp.2.000.000/ } \\
\text { orang }\end{array}$ & Rp.322.000.000 \\
\hline
\end{tabular}


Muklisin ,Iffah Pohan: Penyaluran Zakat Dalam...

\begin{tabular}{|l|l|l|l|l|}
\hline & 2018 & & & \\
\hline
\end{tabular}

Sumber : Dokumen, Penyaluran modal usaha zakat BAZNAS Kabupaten Bungo

Dengan adanya BAZNAS Kabupaten Bungo maka diharapkan mampu menyediakan atau membantu usaha produktif bagi masyarakat sehingga mereka dapat mengembangkan ekonomi keluarga mereka sendiri. Kegiatan industri kecil dan menengah (UMKM) diKabupaten Bungo dapat berpotensi menyerap banyak tenaga kerja yang meliputi bidang pertanian, perikanan, tukang, pengelolaan barang produksi rumah tangga, dan pemanfaatan sumber daya alam.

Hal ini oleh pihak BAZNAS Kabupaten Bungo dapat dijadikan kebijakan yang ditujukan untuk mencapai sasaran pembangunan, yakni meningkatkan produktivitas masyarakat kecil meningkatnya lapangan kerja, dan terciptanya semangat pembentukan iklim sumber daya manusia yang kreatif.Dan secara tidak langsung juga dapat membantu kinerja pemerintahan daerah Kabupaten Bungo.

\section{PENUTUP}

BAZNAS Kabupaten Bungo menyalurkan zakat dalam bentuk modal usaha sehingga diharapkan mampu meningkatkan peningkatan perekonomian khususnya dalam bidang yang bergerak di unit usaha kecil dan menengah (UMKM) di Kabupaten Bungo.Dalam hal ini terkait penyalurkan zakat dalam bentuk modal usahaoleh BAZNAS di Kabupaten Bungo maka diharapkan mampu menyediakan atau membantu usaha produktif bagi masyarakat sehingga mereka dapat mengembangkan ekonomi keluarga mereka sendiri.

\section{DAFTAR PUSTAKA}

Arif Mufraini, Akuntansi Dan Manajemen Zakat ;Mengomunikasikan Kesadaran Dan Membangun Jaringan, Jakarta: Kencana Prenada Media Group; 2006

Ali Hasan, Zakat Dan Infak Salah Satu Solusi Mengatasi Problema Sosial Di Indoesia, Jakarta: Kencana Prenada Media Group : 2008

Muhammad Daud Ali, Sistem Ekonomi Islam Zakat Dan Wakaf, Jakarta : UI Press; 1988

Murni Sumarni, Manajemen Pemasaran Bank, (edisi revisi) ; Yogyakarta; Penerbit Liberti : 1993 
Muklisin ,Iffah Pohan: Penyaluran Zakat Dalam...

Mulyana Deddy, Metodologi Penelitian Kualitatif, Bandung; Remaja Rosdakarya; 2001

Musyidi, Akuntansi Zakat kontemporer, Bandung; Remaja Rosdakarya; 2006

Nuruddin Ali, Zakat Sebagai Instrument Dalam Kebijakan Fiscal, Jakarta; Raja Grafindo Perkasa; 2006

Sondang P. Siagian, Manajemen Strategik, Jakarta : Bumi Aksara, 2005

Said Saad Marathon, Ekonomi Islam Ditengah Krisis Ekonomi Global, Jakarta ; zikrul hakim, cetakan ke 3, 2007

Yusuf Qardhawi, Hukum Zakat, Studi Komparatif Mengenai Status Dan Filsafat Zakat Berdasarkan Quran Dan Hadist, Cetakan ke 7, Jakarta ; Pustaka Litera Antarnusa, 2004

Zaki Muhammad. "Faktor-Faktor Yang Mempengaruhi Muzakki Untuk Membayar Zakat Melalui Badan Amil Zakat Daerah (BAZDA) Kabupaten Bungo, Provinsi Jambi". Tesis, Program Pascasarjana IAIN Sumatera Utara, 2012 